\title{
Short-Run Money Growth Volatility: Evidence of Misbehaving Money Demand?
}

\author{
SCOTT E. HEIN
}

$\mathrm{T}_{\mathrm{H}}$ tranquil for the U.S. economy. Interest rates, for example, have been high and volatile. Twice during this period they rose to record levels: the prime rate hit 20 percent in April 1980 , then rose to 21.5 percent in January 1981. Two recessions have occurred during this brief period, one of which apparently still lingers. Significant financial changes have taken place with an infux of deposits into money market mutual funds and an outflow from small time and savings deposits. The nationwide legalization of NOW accounts in early 1981 also resulted in a sizable reallocation of funds. Amid all of these developments, money growth also has been quite volatile.

Should the volatility of short run money growth be a matter of concem? There appear to be two distinct schools of thought with regard to this question. One school argues that such volatility is not really a problem. It holds that "the need for precise short-run money supply control is technically questionable." The other school argues that such volatility damages the economy. For example, Milton Friedman, in evaluating monetary policy over the last couple of years has written that "the yo-yo swings in monetary growth affected the economy directly, as well as through interest rates. Each surge in monetary growth was followed after some montlis by an atcceleration in spendable income, output and em-

\footnotetext{
"Stephen $\mathrm{H}$. Axilod and David $\mathrm{E}$. Lindsey, "Fegeral Reserve System Implementation of Monetury Policy: Analytical $F_{0} \ngtr a n-$

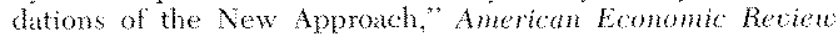
Papers and Proceding (May 1981 ) p. 252. Also, see GeorgeW. Mckinney Jr., "The Nime of the Gome" Ecomomic View from One Wall Sheet (February 26, 1982).
}

ployment; and each decline in monetary growth, by a retardation."2

Somewhat surprisingly, the two schools do not disagree about theoretical issues. Both schools agree that, in theory, the desirability of stabilizing shortrun money growth depends on the stability of the public's demand for money. Achieving stable money growth benefits the economy only if the public's demand for money does not change amexpectedly.

The issue that separates the two schools of thought is chiefly an empirical one: has money demand been reasonably stable? Those who argue that the volatility of short-run money growth in the past has not been a problem hold that money demand has been subjected to a series of unpredictable shifts. According to this reasoning, holding the rate of money growth in a tight band would have imposed significant costs on the economy. Suppose, for example, the public wants to hold larger money balances. If such a preference is thwarted by an adherence to pre-established monetary targets, the economy would be subjected to unnecessary restraint. Indviduals seeking to build their money balances will reduce their demand for goods and services and financial assets, resulting in an economic slowdown.

The other school argues that money demand has been basically stable. In this view, as Friedman contends, rapid money growth overstimulates the economy, ultimately causing inflation, while sluggish money growth imposes undue restraint.

"Mitton Friedman, "The Yo-Yo Economa "Neasueck (February 15, 1982). Also, see Milton Friedman, "The Federi heserve and Monetary Instability, "Wall Street fom mal, February I, 1982. 
This article examines the evidence to determine whether money demand behavior over the last two years has been erratic enough to justify the observed volatility in money growth.

\section{NOB

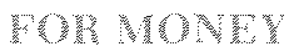

Chart 1 provides evidence on short-iun (quarterly) money growth volatility. The chart plots, for each quarter since II/1962, quarterly money growth (at an annual rate) less the average of money growth over the prior 12 quarters. Thus, for example, the -2.0 percent reading for $11 / / 1962$ shows that money grew 2 percentage points less in that quarter than its average growth rate in the previous three years.

The volatility shown in this chart has two different dimensions. One dimension is simply the magnitude of the deviation from trend. For example, in the third quarter of 1980 , money grew at a rate 8 percentage points above trend, the largest positive deviation in the last 20 years. In the second quarter of 1980 , money grew at a rate over 10 percentage points below trend, the largest negative deviation in the last 20 years. Thus, according to such a measure, money growth has been quite volatile over the last two years.

The second dimension is the frequencty with which deviations of money growth relative to trend change signs. The chat shows that money growth relative to trend frequently has changed sign from positive to negative, and vice versa, over the last two years. This fluctuation stands in shap contrast to the historical norm whereby money growth usually is above or below trend for several quarters in a row. Thus, the increased frequency of change of quarterly money growth relative to trend also supports the view that money grow th over the last two years has been volatile.

The increased volatility in money growth alone does not demonstrate that the demand for money was unstable. Such a condusion implicitly holds that the grow th of the nominal money stock is completely demand-determined, ignoring completely the actions taken by monetary authorities. Since monetary authorities can change bank reserves, reserve requirements or the discount rate, it is entirely possible that changes in nominal money grow th reflect their actions, instead of shifts in the public's desired money holdings. In other words, monetary author- ities "can 'create' a product without necessarily being limited by the demand for it." 3 Thus, one should not necessarily interpret changes in money growth as shifts in money demand.

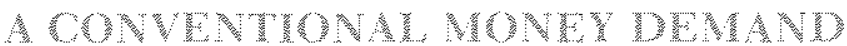

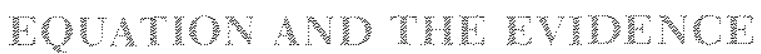 m}

One can analyze money demand on a more sophisticated basis by using econometric techniques. This article provides no new analysis on this topic; instead it describes how such evidence can be evaluated.

Economic theory holds that nominal money balances relative to the general price level (generally called "real" money balances) are the relevant quantity measure for demand analysis (just as standard demand theory explains the demand for physical goods and services, not the dollar value of those goods and services). Thus, when one focuses on real money, one recognizes that the usefulness of money clearly depends on the price of goods and services. For example, if the quantity of money that people hold remains unchanged while the average price of goods and services fall, a given stock of money will have greater value; that is, it will permit the purchase of more goods and services. Thus, the economically meaningful measure is the money stock relative to the average price of goods and services. ${ }^{4}$

Analysts commonly hypothesize that real money balances move opposite to a change in market interest rates and in tandem with a change in real income. A change in market interest rates negatively affects the demand for real balances, because it represents the opportunity cost of holding money. If market interest rates rise, individuals forgo more interest income by holding money and thus are $e^{x}$ pected to desire less money balances. As real income rises, however, individuals will want larger real money balances to purchase more goods and services. Thus, a change in real income is expected to have a similar effect on desired real money balances.

\footnotetext{
SStephen H. Axilrod, "Monetary Policy, Money Supply, and the Federa Resere"s Operating Procedures," Federil Reseret Bulletin (January 1982), p. 13 .

${ }^{4}$ For a disetsion of the interpetion of changes in teal balances, see A. B. Balbach and Denis 5 . Kumosky, "Real Money Balances: A Cood Forecasting Device and " Cood Policy Target" this Retew (September 1975 ), po. 11-15.
} 


\section{Chart 1 \\ Quarterly MI Growth Relative to Trend}

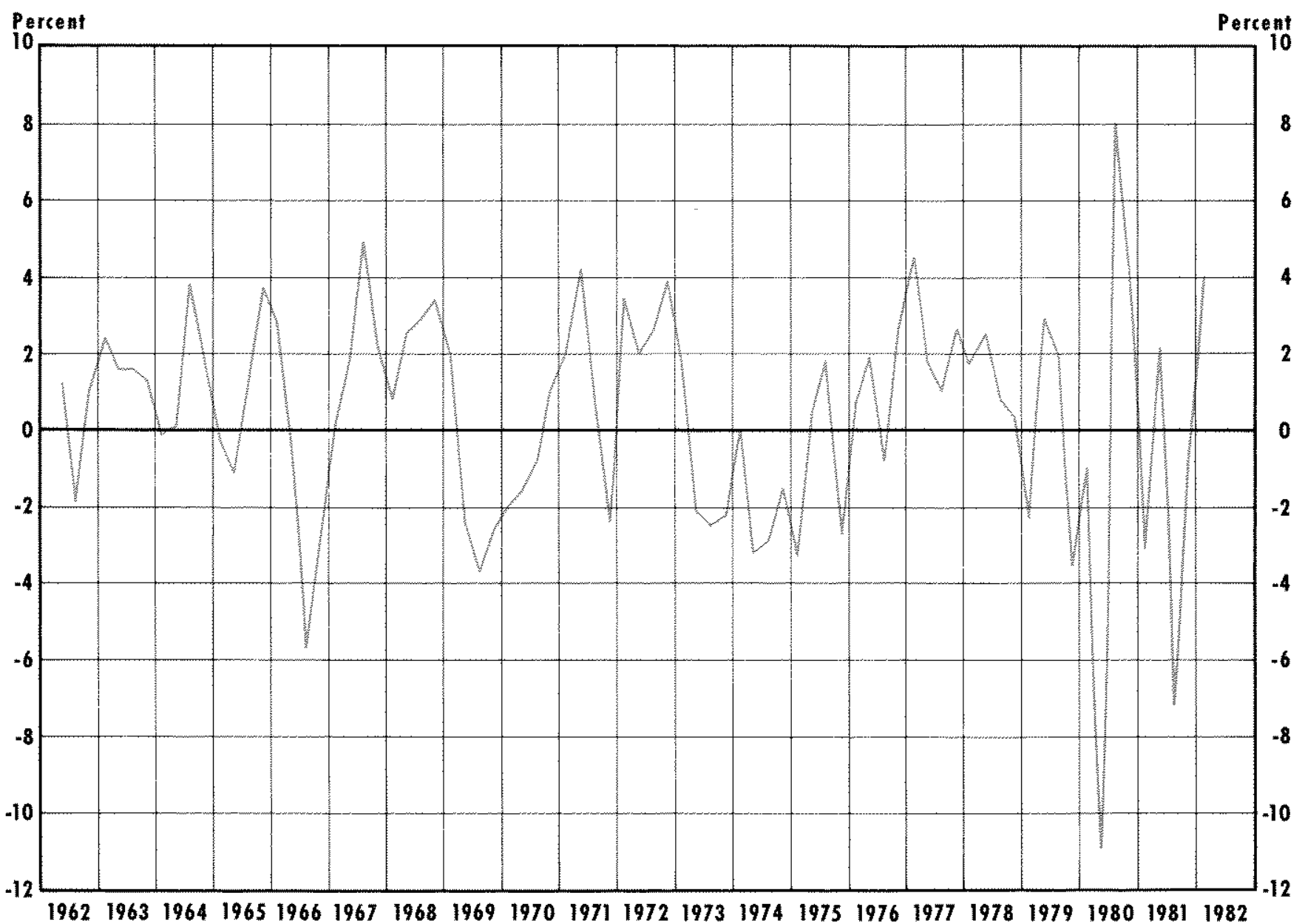

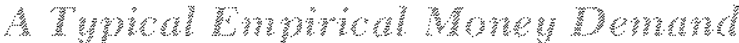 Tenturion}

To empirically investigate the demand for money, the relationship between real money balances (M/ $P)_{t}$ and current interest rates $\left(i_{t}\right)$, real income $\left(y_{t}\right)$, and lagged real balances $(\mathrm{M} / \mathrm{P})_{\mathrm{t}-\mathrm{t}}$, is estimated using multiple regression analysis. The equation to be estimated is typically written as:

(1) $(\mathrm{N} / \mathrm{P})_{\mathrm{t}}=\beta_{0}+\beta_{1} \mathrm{i}_{\mathrm{t}}+\beta_{2} \mathrm{y}_{\mathrm{t}}+\beta_{3}(\mathrm{M} / \mathrm{P})_{\mathrm{t}-1}+\epsilon_{\mathrm{t}}$.

The coefficients $\beta_{0}, \beta_{1}, \beta_{2}$ and $\beta_{3}$ show how desired real money balances respond to changes in the respective independent variables. The residual, $\epsilon_{t}$, is assumed to be a random variable that fuctuates about zero. It represents the unexplained variation of actual real money balances from that predicted by the combination of the estimated regression coefficients and the values of the independent variables.

Last period's real balances are usually included in empirical estimations of money demand to capture an assumed adjustment process. Because of relevant transaction costs of adjusting real money balances, it is usually presumed that actual balances only slowly adjust to desired levels. The lagged value of real balances is included to capture such an adjustment process. By including lagged real money balances in the equation, we are assuming actual real balances only partially adjust to current changes in interest rates or real income.

A common procedure used in evaluating the behavior of money demand is to consider how well 
an empirical relationship such as equation 1 simulates or predicts actual real money balances beyond the estimation period. ${ }^{5}$ Chat 2 plots the level of real money balances simulated with equation 1 and the actual real money balances for the out-of-sample interval $\mathrm{V} / 1980-\mathrm{I} / 1982{ }^{6}$ Table 1 summarizes these results using a variety of statistical measures. ${ }^{7}$

This proced are apprarent y dates back to Stephen W. Goldeld, "The Case of the Missing Money,"Brokings Paners an Loounic Articity (3:1976), 1p. 683-730. One crucial difference between Goldfeld sovidence and more recent interpretations is that Goldela provded evidence of sustained one-sided simuhation enor. Logically, Goldfeld's findings suggest a shift. More recent discussions incoxectly deduce a shift from in single period's smanlation emor. This point is subsequently mone fully developed. For a more recent application, see Brian Motley, "Inmovation and Money Denzand," Federal Reserye Bank of San Franciseo Welly Lefter (Jamary 1, 1989).

6Estimating equation 1 in natural log ( 1 in form vields the fol lowing coefficient estimates and summary statistics for the $I$ 1960-IV/1979 sample period absolute value of t-statistics in parentheses):

$$
\begin{aligned}
& \text { (1) } \ln (\mathrm{M} / \mathrm{P})_{\mathrm{t}}=0.34+0.07 \ln \mathrm{y}_{\mathrm{t}}-0.01 \ln \mathrm{RCP} \\
& \text { (1.41) (3.9.4) (3.27) } \\
& +0.85 \mathrm{ln}(\mathrm{M} / \mathrm{P})_{\mathrm{i}-1}-0.02 \mathrm{Dl} \\
& (13.69) \quad(3.89)
\end{aligned}
$$

$\overline{1}^{2}=0.94$

where $M$ is Ml, is the GNP deflator, $y_{+}$is real GNP, ant RCP is the commercial paper rate. ${ }^{5}$ The estmated coefficient on $1 n y_{t}$ (0.07) indicates that a 1 percent increase in real income this quarter is usually associated with a 0.07 percent incredse in real money balances. In a similar vein, the interest rate coeffcien suggests that a 1 percent increase in metest rates (for example, from 10.0 percent to 10.1 percent) will lead to a 0.0 .1 percent decline in real balinces. Finally, the coefficient on lagged real balunces (0.85) indicates that real balares will adjust to desired levels at at mate of 15 percent $(1.00-0.85)$ per quater. Thus, the long-run response to changes in interest rates and real ineore is much higher than the short-nun response. In the out-of-sample simulations reported betow, these coefficients along with actual values of the right hand side variables are used to project the dependent variable.

This relationship is similaz to that in R. W. Haler and Scott $\mathrm{E}$. Hein, "The Shift in Money Denand: What Really Happened?" this Retieu (Febnary 1982), po. 1].16. However, the passook rate variable is exched since its coefficient was insignificme The equation was estimated using the Hatanaka two-step procedure to correct for first-order serial comelation in the residuals. Dl is a dummy variable that takes on a valtae of ] after I/1974, capturing a one-time sheft in the demand for money. The stan dard eror of the estimated regression is 0.0045 and the estimate of the serial correlation coefficient is 0.35 .

The equation simulates the natrual log of feal Ml balances. Tabls 1 presents the antilog of these simulated values, that is, levels of real money balances. Such a transfomation, being nonlinear, will not yed optimal predictions. However, it does yeld a better "feel" for the size of errors.

These simulations are static (when actual values of the lagged dependent variable are used) rather than dvainic (when predicted values of the lagged depentent variable are used). See Scott E. Hein "Dynamic Forecasting and the Demand for

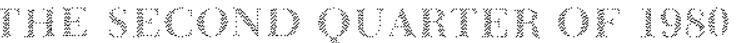

Much hoopla has been made of the difference between the simulated real balances in the second quarter of 1980 and the actual balances at that time. Real money balances in that period tumed ont to be almost $\$ 7$ billion below what equation I' predicted. Such a finding has been interpreted as evidence that money demand shifted downward significantly in II $/ 1980$.

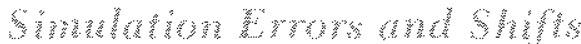

Equating a "shift" with a simulation enror, however, is clearly inappropriate. Deviations of real batances from predicted or simulated values do not provide evidence of a behavioral shift in the relationship. Recall that when the equation is estimated, it is assumed that actual real money balances will fluctuate randomly around its predicted or simulated level. By assumption, the actual and simulated real money balances will usually deviate from each other by some unknown random value. Thus, we should expect similar fluctuations to oceur outofsample. When considering only one simulation error, it is impossible to ascertain whether one is observing a shift (as represented by a change in one of the coefficients), or simply a large random fluctuation. ${ }^{8}$

When the deviations are consistently one-sided, however, one can conclude that at "shift" in the behavioral relationship has occurred (i.e., one of the coefficients, $\beta_{0}, \beta_{1}, \beta_{2}$ or $\beta_{3}$, has changed). Chart 2 , however, shows no evidence of consistent one-sided errors. Thus, there is little evidence from these simulations to indicate a "shift" in the behavioral relationship.

Moreover, recognize that if policymakers incorrectly equate prediction errors with shifts in money demand, then they will view any observed behavior in real money balances as correct. Thus, in either the case of rapid or slow money growth, no corrective action would be called for. However, if these disturbances are not true shifts in money demand, policymakers will actually allow money growth to fuctuate more than necessary.

Money," this Retien Uneduly 1980, pp. 13-23, where it is argaed that static forecast erors provide a better foundation from which to judge shifts in the demand for money.

8This is true regardless of the size of the exror, because there is al ways a positive probability of drawing from the extreme tails of a normal probability distribution. 


\section{Chart 2 \\ Actual and Simulated Real MI}

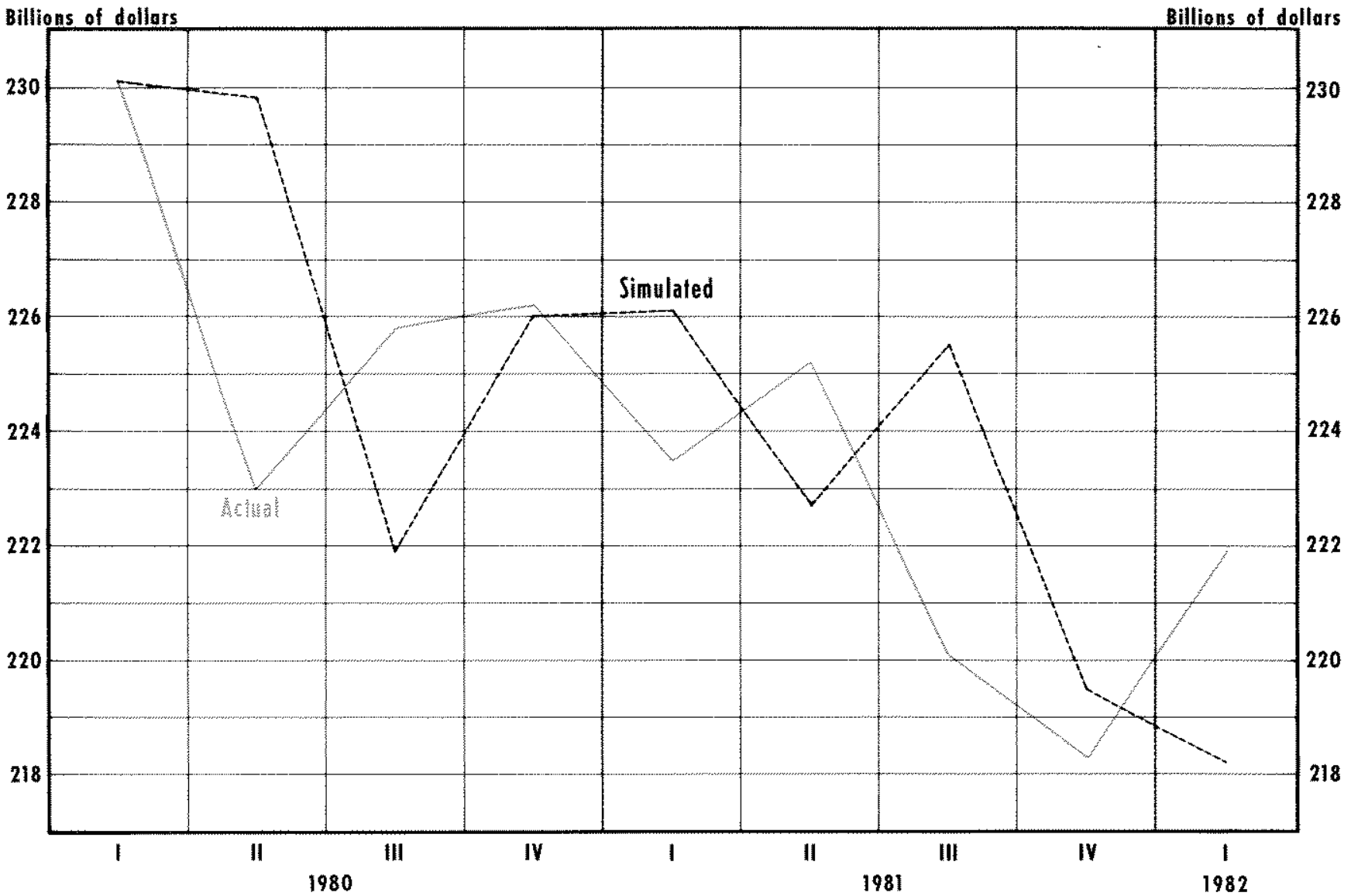

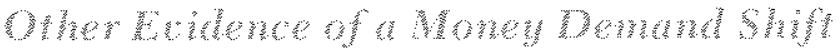

Few who argue that a shift occurred in II/1980 base their case on the one simulation error of chart 2 , however. Two auxiliary arguments also are used to support the notion that there was at downshift in money demand. One argument is that a downshift occured "in response to the very high and record levels of short-tem interest rates reached in early spring." This argament holds that a sharp rise in interest rates, especially one that pushes rates beyond previous peaks, causes fims and individuals to institute new cash management techniques, ${ }^{10}$

"Axilnod and Lindsey, "Federal Reserve System Implementation of Monetary Policy," p. 251

100 ne of the earliest esponsals of this hypothesis can be fomd in Richard D. Porter, Thomas D. Simpson, and Eileen Mauskopf,

"Financial Innovation and the Monetary Aggregates," Brokk"
These techiques, once in place, lead to permanent decreases in desired real money balances relative to a given level of real income and interest rates. In other words, money demand shifts downward following a sharp rise in interest rates. Such an argument has been used to explain the abnomal behavior of money demand since 1974 and is used now to bolster the evidence of another downshift.

Chat 2 proves false this explanation of the $11 / 1980$ decline in real balances. Were there actually a decline in the demand for real cash balances caused by individuals and fims instituting new cash management techniques in response to high interest rates, one should observe a level of real money balances that is consistently below simulated levels following the "downshift."

ings Papers on Economic Acticity $(1,1979), 0 p .213-29$ 


\section{Table 1}

\section{Out-of-Sample Simulations of a Money Demand Equation (billions of dollars, seasonally adjusted)}

\begin{tabular}{|c|c|c|c|}
\hline Date & $\begin{array}{l}\text { Actual: } \\
\left(\mathrm{M}_{\mathrm{t}} / \mathrm{P}\right)\end{array}$ & $\begin{array}{l}\text { Simulated } \\
\left(M_{t} / P_{t}\right)\end{array}$ & Eror \\
\hline $1 / 1980$ & $\$ 2301$ & $\$ 230.1$ & 0.0 \\
\hline $11 / 1980$ & 2230 & 2298 & -68 \\
\hline $11 / 1980$ & 2258 & 2219 & 3.9 \\
\hline IVt 980 & 2262 & 2260 & 02 \\
\hline 11981 & 2235 & 2264 & 29 \\
\hline $1 / 1981$ & 2252 & 2227 & 2.5 \\
\hline $11 / 981$ & 2201 & 2255 & -5.4 \\
\hline $1 / 1981$ & 2183 & 2195 & 12 \\
\hline 11982 & 2219 & 2182 & 3.7 \\
\hline \multicolumn{4}{|c|}{ Summary statisties } \\
\hline \multicolumn{3}{|c|}{ Meanetrot } & 0.6717 \\
\hline \multicolumn{3}{|c|}{ Mean absolute error } & 29621 \\
\hline \multicolumn{3}{|c|}{ Rootmean-squared errot } & 36635 \\
\hline \multicolumn{3}{|c|}{ Thefls nequaliy coeffelenl -} & 00064 \\
\hline \multicolumn{3}{|c|}{ fracton of errordue to } & \\
\hline \multicolumn{3}{|c|}{ (A) Bras } & 0.03 \\
\hline \multicolumn{3}{|c|}{ (B) Vanations } & 000 \\
\hline \multicolumn{3}{|c|}{ (C) Co-variation } & 094 \\
\hline
\end{tabular}

Actual less simulated

If this shift were pemanent, as this argument suggests, the prediction error should remain negative for all quarters after I/1980. Chat 2 shows, however, that the equation does not consistently overpredict real balances after [//1980. Actual real balances in $I 1 / 1980$, instead, were slightly higher than the relationship would suggest, Further, real balances were slightly higher, on average, than the equation implies for the full III/1980-1/1982 period. Thus, one cannot empirically support the argument that a persistent, sizable downshift in money demand was precipitated by record interest rates in II/1980.

The second argument in stapport of a money demand downshift in II/1980 contends that the imposition of credit controls in March 1980 was responsible for a decrease in desired real balances. Such an argunent contradicts conomic theory, however. With credif controls explicitly limiting the extension of bank credit, haviduals and business firms would desire larger money balances for anticipated transactions or precautionary purposes. Thus, theory suggests an increase in money demand during this period, not a decrease.

Thus, both auxiliary arguments in favor of a behavioral shift in money demand in II/1980 lack either logical foundation or supportive empirical evidence. Moreover, if there was a behavioral shift in money demand, the excess supply (supply exceeding demand) of money must have been offset by an increase in demand elsewhere. In other words, if economic participants actually wanted less money balances, they must have desired more of something else in exchange. There is little eviclence, however, of increased demand for labor, goods and services, or financial assets in the economy.

Further, the generally declining interest rates in this period do not necessarily suggest a behavioral downshift in money demand as many insist. Declining interest rates do suggest an excess supply of credit, which can come about either because of an increase in credit supply or a decrease in credit demand. Only an increase in the supply of credit (as individuals become more willing to give up money today in exchange for a promise of money in the future) would be consistent with the notion of a downshift in money demand in II/1980, since there is no evidence of an increased demand elsewhere which would be required to offset the decreased demand for both credit and money. Yet, there appears little evidence of an increased supply of credit in this period. Chart 3 shows that the total funds raised by nonfinancial sectors declined markedly in II/1980. Thus, the fall in rates in the seomd quarter of 1980 is better explained by weakening credit demands associated with the recession, wather than the increased supply of credit.

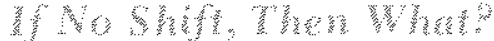

If money demand did not shift in II/1980, why were real money balances low relative to predicted levels? Perhaps the irregular behavior ocoured on the "supply side." Robert Weintrab has suggested, for example, that slow money growth resalted from an mexpected decline in the money multiplier the ratio of Ml balances to the monetary base), in response to a sizable shift in the desired cmrency holdings, as consumers becme wary about the acceptability of credit cards during the control pe- 
Chart 3

\section{Credit Market Funds Raised by Nonfinancial Sectors}

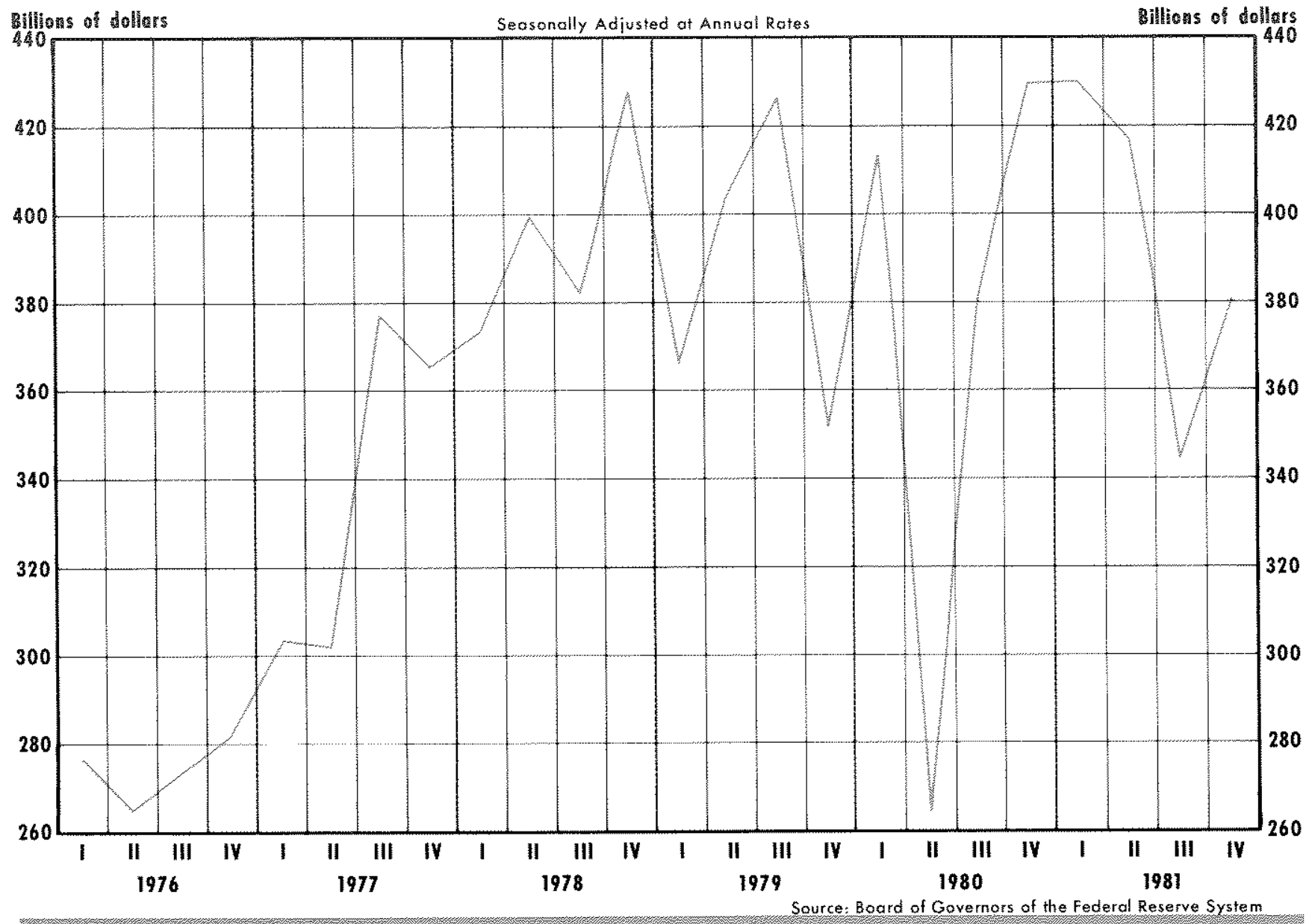

riod. ${ }^{11}$ Such a change would drive up the currencydeposit ratio and reduce the money multiplier.

If the money multiplier declines, banks have to reduce the amount of deposits they oreate for a given amount of source base (or bank reserves). According to Weintraub's hypothesis, M1 balances declined because monetary athorities did not anticipate the increased demand for currency and offset it by increasing the base. Therefore, the observed dechine in real money balances was due, not to a reduction in the demand for real balances, but to this unanticipated change in the supply of money caused by an increased demand for currency as a result of the credit controls.

1ERobert Weintraul, The Imuact of the Federal Reseres System's Monetary Polcies on the Nation's Economy (Second Report), Staff Report of the Subcommittee on Domestic Nonetary Policy, House Committee on Banking, Finance and Uban Affars, 96 Cong, 2 Sess. (Govemment Printing Offee, 1980), p. 17
Although individuals wanted to hold as much, if not more, MI balances following the imposition of the credit controls, the banking system precluded these demands from being satisfied. Once credit controls were removed, the Weintraub hypothesis suggests, the multiplier would come back within its historical ranges (see chart 4 ). Thus, real money balances could be expected to return to more historical levels as well. This is indeed what happened: actual real balances rose to about $\$ 226$ billion in III/1980 (see chart 2).

Therefore, one can interpret the behavior of real balances in II/1980 as evidence of a supply-side limitation, not a decrease in the demand for money. In this light, the large simulation error is merely evidence of temporary disequilibrium, Real money balances deviated from predicted levels, not because individuals desired less money, but because monetary authorities did not anticipate the effect of 


\section{Multiplier and Ratio of Currency to Total Checkable Deposits}

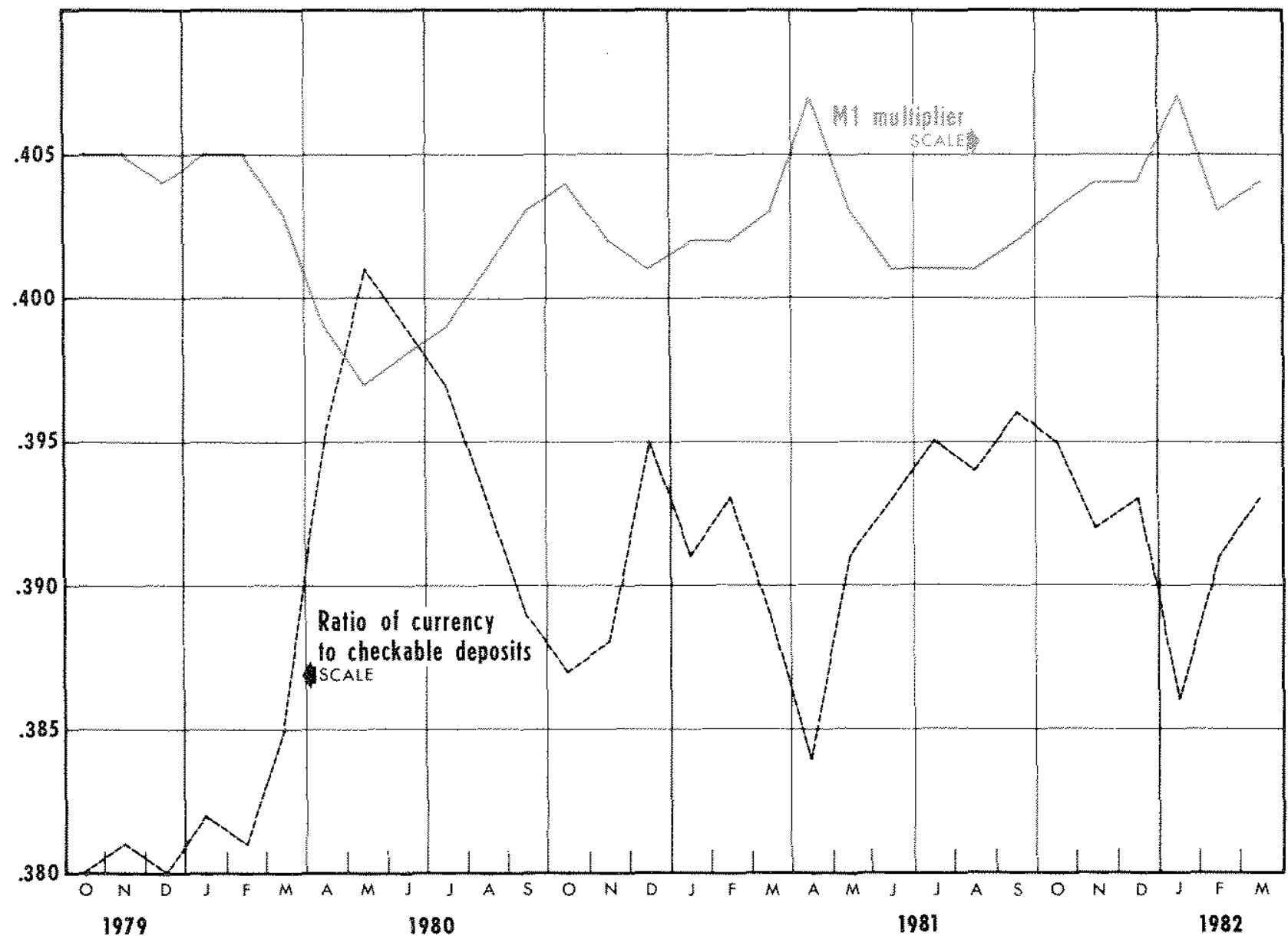

credit controls on the way people decided to hold their money.

John Judd and John Scadding also argue that "the rapid monetary deceleration in the second quarter of 1980 (as well as the rapid growth in the first and third quaters) was calsed, not by a money-demand shift, but by a money-sumly 'shock."12 While disagreeing with Weintraub about the mechanies of the supply shock (Judd and Scadding trace the supply shock to the contraction in bank loins that followed

12John P. Judd and John L. Scadding, "Liability Management, Bank Loms, and Deposit "Warket" Disenuilbrim," Federal Reserve Bank of San Franciseo, fomomic Rethe: (Summer $1981), 21$ the Spectal Credit Control Program of 1980), Judd and Scadding, like Weintrabb, recognize that "changes in the sumply of money can dominate shortram movements in the monetary aggregates." 13 The important point here is not to differentiate between the Weintrab and fudd-Scadding hypotheses, but to recognize that both views explain the contraction in money growth by supply-side occurences. Thus, deviations of actual real balances from those simulated by a money demand equation may be evidence of supply shoeks, rather than demand shifts as many suggest.

is bid., p. 22 . 


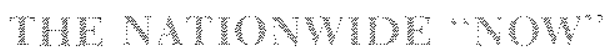

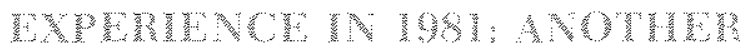

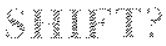

The simulated values of real money balances also allow an evaluation of the impact of the nationwide legalization of NOW accounts on the demand for money. It has been argued that the introduction of NOW accounts might result in an increased demand for Ml balances, supposedly because of the explicit interest paid on such balances. ${ }^{14}$

The Federal Open Market Committee (FOMC) apparently believed such a result likely. In the first place, the FOMC increased the targeted growth ranges for $M 1$ balances in 1981 . In addition, the staff of the Federal Reserve Board of Governors developed a "shiftadjusted" M1 measure that would subtract the "artificially induced" demand resulting from the nation wide introduction of NOW accounts. This adjustment was determined, in large part, by surveying new NOW account depositors about the original source of the funds they deposited into these accounts. Asking such a question, however, provides little, if any, information about desired money holdings. ${ }^{15}$ An analysis of a conventional money demand relationship should be a better vehicle to address this issue.

If the nationwide legalization of NOW accounts had actually resulted in an increased desire to hold Ml balances, the conventional money demand relationship should have consistently underpredicted real balances after the nationwide introduction of these accounts. In other words, actual (real) Ml balances should have been consistently above the level simulated by the equation, as individuals held

\footnotetext{
14uch of the discussion about the impact of Now aceonts has centered on the minimum balance recularements of such are comnts. Since minimum balance refuirements are higher on Now acconts than on conventional ememand deposits, it has been argued that Ml will grow. David E. Lindsey, "Nonborrowed heserve Targeting and Monetary Control, "paper presented at Economic Policy Conference on "Improving Money Stock Control: Problems, Solutions, and Cansequences, pats corretly pointed out, however, that the isste is one of meney dematnd. No adfustment need be made if the demand for MI remains tunchanged.
}

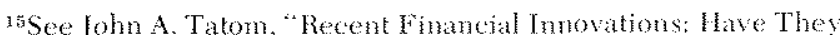
Distorted the Meming of Mu?" this Rece (April 1982), pp. 23-35. Some have argued that the shift adjustment was developed to capture the soures of NOW in How's ather than the nes: Such an adjustment should wot have been incomporated in the taryeting of the money atgrgregates then! larger-than-expected balances. In chart 2 , where observed (not shift-adjusted) real money balances are shown, however, no consistent underprediction occurred during the last five quarters. In fact, the equation slightly ocerpredicts real money balances. Thus, it does not appear that the nationwide legalization of NOW accounts increased desired MI balances in any important way ${ }^{16}$

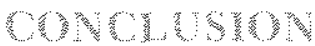

Many analysts of monetary policy have used the recent financial innovations and the volatility of money growth as ammunition against pre-established monetary growth targets. These innovations supposedly have caused unpredictable swings in money demand. The behavior of actual money growth has been taken as evidence of such swings.

This article offers a counter argument. To begin with, swings in money growth are reliable indicators of money demand only to the extent that the supply of money has not itself been shocked. In the face of such shocks, large fluctuations in money growth camot be interpreted as evidence of money demand shifts. The second quarter of 1980 was an episode of unusual money growth caused, not by shifting money demand, but rather by supply-side occurrences. $M 1$ balances fell because the banking system was unable to support the public's desired deposit levels. The lesson learned from this episode is that

\footnotetext{
w While no appatent irregularities exist when $M 1$ is used this is not the case when the shiftadiusted meastre is employed. Wany have recognzed this fitet. See, for example, Molley, "Innovation and Money Demand:" and Fohn Weminger, Lawrence Radecki and Elizabeth Hammond, "Recent Instability in the Demand tor Money, "Federal Reserve Bank of New York Quartehl Retien (Smmer 1981), p1, 1-9, where many explanations of such anomalous behavior are provided. The point of the present article, however is that steh explathations are not required. A puzale exists only when the questionable shiftadjusted measure is used. Just beconse indviduals are moving funds from savings to NoW ateounts does not ind fatte,

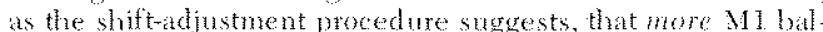
ances are desired. There are always people moving fumds from

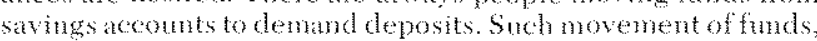
however, have never before been taten fo suggest that the demand deposit measure should be adnsted. Why should such movenents of tunds now provide iny nore ase ful information? While it is clenty possible that the inteduction of explacit interest payments on checkable deposits did result in an increased demand for Ml balances, smveying individuals to fnd out whe funds for new Now accounts came from is not going to be use tal in ackdressing such an issuce Examining a money demand equation, which is a useful procedure, shows no evidence of an inctersed temat.
} 
one-time deviations of real money balances from predicted levels do not necessarily indicate a shift in money demand. Such a deviation could just as well denote a temporary money mathet disecuilibrium, caused by the growth of the money supply or a random fluctuation.

One precondition for a "shif" in money demand is a set of consistent, one-sided prediction errors, derived from an estimated money demand relation- ship. A conventional money demand equation, however, shows evidence of neither sustained periods of overprediction (a downshift) nor sustained periods of underprediction (an upshift) in the underlying empincal relationship, Thus, while significant financial imovations have ocenred in the last two years, there is little evidence that these imovations resulted in money demand shifts. The Ml measure continues to have significant economic and policy content. 